10-1948

\title{
The fungus Lagenidium callinectes Couch (1942) on eggs of the blue crab in Chesapeake Bay.
}

Rosalie Rogers-Talbert

Virginia Fisheries Laboratory

Follow this and additional works at: https://scholarworks.wm.edu/vimsarticles

Part of the Aquaculture and Fisheries Commons

\section{Recommended Citation}

Rogers-Talbert, Rosalie, "The fungus Lagenidium callinectes Couch (1942) on eggs of the blue crab in Chesapeake Bay." (1948). VIMS Articles. 1848.

https://scholarworks.wm.edu/vimsarticles/1848

This Article is brought to you for free and open access by the Virginia Institute of Marine Science at W\&M ScholarWorks. It has been accepted for inclusion in VIMS Articles by an authorized administrator of W\&M ScholarWorks. For more information, please contact scholarworks@wm.edu. 


\title{
THE FUNGUS LAGENIDIUM CALLINECTES COUCH (1942) ON EGGS OF THE BLUE CRAB IN CHESAPEAKE BAY ${ }^{1}$
}

\author{
R. ROGERS-TALBERT ${ }^{2}$ \\ Virginia Fisheries Laboratory, Yorktown
}

In 1941 a parasitic fungus was first observed on the eggs of many blue crabs obtained from natural spawning areas in Chesapeake Bay (Sandoz, Rogers, and Newcombe, 1944). Dr. John N. Couch of the University of North Carolina kindly examined infected samples and recognized the parasite to be a new species, which he named Lagenidium callinectes Couch (1942).

Marked annual fluctuations in the commercial catches of the blue crab Callinectes sapidus Rathbun (1895) have taken place. The discovery of the egg parasite raised the questions of how it affects the development of the crab embryo, what percentage of the eggs of a crab may be infected, and how widely the parasite is distributed in Chesapeake Bay. Conceivably, such a parasite could constitute a serious biological factor limiting the production of crab larvae and causing, at least in part, yearly fluctuations in the commercial population.

Laboratory and field studies were carried out: (1) to ascertain the conditions of existence of the parasite in the individual crab eggs as well as on and in the egg mass (commonly called "sponge") ; (2) to show how readily infection may be transmitted under certain conditions; (3) to indicate the effects of salinity and temperature on the survival and development of the fungus; and (4) to show the areas of Chesapeake Bay in which it occurs and the approximate degree of infection.

Acknowledgment is made to all persons who aided in this study. Special thanks are expressed to Professor John N. Couch of the University of North Carolina, who identified and described the fungus parasite; to Mr. John C. Pearson, Dr. Sewell H. Hopkins and Mr. R. Winston Menzel for certain crab collections; to Geo. W. Amory, Jr., W. J. Bradshaw, Jr., Chesapeake Crab Co., Costin Co. Inc., G. T. Elliott, Inc., V. S. Lankford, M. F. Quinn, and O. R. Mills for cooperation in making the collections possible; to Mrs. Ruth E. Allen for the use of illustrations; Mrs. Mildred D. Sandoz for helpful counsel; and especially to Dr. Sewell H. Hopkins for valuable criticism of the manuscript. This work was done under the direction of Dr. Curtis L. Newcombe, formerly director of the Virginia Fisheries Laboratory.

\section{Biology of the Blue Crab}

The blue crab, Callinectes sapidus Rathbun, occurs abundantly in Chesapeake Bay and provides the source for a major seafood industry in the Tidewater section

${ }^{1}$ Joint contribution from the Virginia Fisheries Laboratory of the College of William and Mary and Commission of Fisheries of Virginia (Number 28), and from the Department of Biology of the College of William and Mary.

2 Present address : Department of Zoology, University of Wisconsin, Madison, Wisconsin. This work was done in partial fulfillment of requirements for the degree of Master of Arts at the College of William and Mary. 
of Maryland and Virginia. The annual production of the raw product of these crabs is valued at more than a million dollars. ${ }^{3}$

Churchill (1919) made studies on the life history of this species in Chesapeake Bay. He found that the average blue crab lives two to three years during which time definite migrations take place throughout the bay. In the spawning season, which lasts from May to September of each year, large numbers of egg-bearing females are found in the waters at the mouth of the bay-in the vicinity of Cape Charles and in Hampton Roads (Fig. 1). The gravid female carries her eggs on four pairs of small abdominal appendages (pleopods). These appendages are provided with many hair-like filaments to which the eggs become attached by a glandular secretion when they are extruded from the oviduct (Fig. 2). Incubation is completed in about two weeks in Chesapeake Bay. An egg mass or sponge is estimated to contain about 2,000,000 eggs. The writer has observed that sponges vary a great deal in size, averaging $75 \mathrm{~mm}$. wide, $50 \mathrm{~mm}$. long, and $40 \mathrm{~mm}$. deep. The bulk of so many eggs forces the folded abdomen (apron) away from the ventral side of the cephalothorax until it extends almost posteriorly. Observations have indicated that there is uniform development within a blue crab sponge (Lockhead and Newcombe, 1942), only 1 to 4 per cent of the eggs showing a retarded or undeveloped condition.

The approximate age of crab embryos can be determined by the color of the sponge. A new sponge is bright orange or yellow due to the large amount of yolk material in the egg. With development, the color of the sponge darkens to brown and finally black as the nutrient yolk is used up and pigment spots appear. Thus, age may be designated by three colors : Yellow, representing the first to the fifth day after eggs are deposited; brown, the sixth to the eleventh day; black, the twelfth to the fifteenth day.

Hatching releases zoeal larvae which are abundant in the plankton of the lower bay waters. After passing through at least five zoeal instars (Hopkins, 1944), a second larval stage, the megalops, is attained. There is a single megalops instar ${ }^{4}$ which molts directly into the first crab stage. The young crabs begin to migrate up-bay or into the near-by rivers. Such crabs hibernate in these waters during the winter, then complete their development and mate the following summer. After mating, if not before, the females begin a migration to the natural spawning area in the vicinity of the Capes. Many arrive in the lower bay at the end of their second summer. They winter here and produce their eggs when conditions become favorable the following year. A large proportion of the females which mate late in their second summer may winter en route to the capes. Many of them produce their sponges the next summer before they reach the spawning grounds. This partially accounts for the large number of females with yellow sponges and the very few with dark sponges contained in commercial catches of the Egg Island-York Spit area (Fig. 1).

Adult male crabs do not make an extensive southward migration as do the

${ }^{3}$ For the period 1939-1943 the average annual production of raw product in Chesapeake Bay was $42,807,050$ lbs., averaging an annual value of $\$ 1,327,882$. Fishery Statistics of the $U$. S., Fish and Wildlife Service, U. S. Dept. of Interior.

4 M. D. Sandoz, in unpublished data on development of the blue crab, Virginia Fisheries Laboratory. 


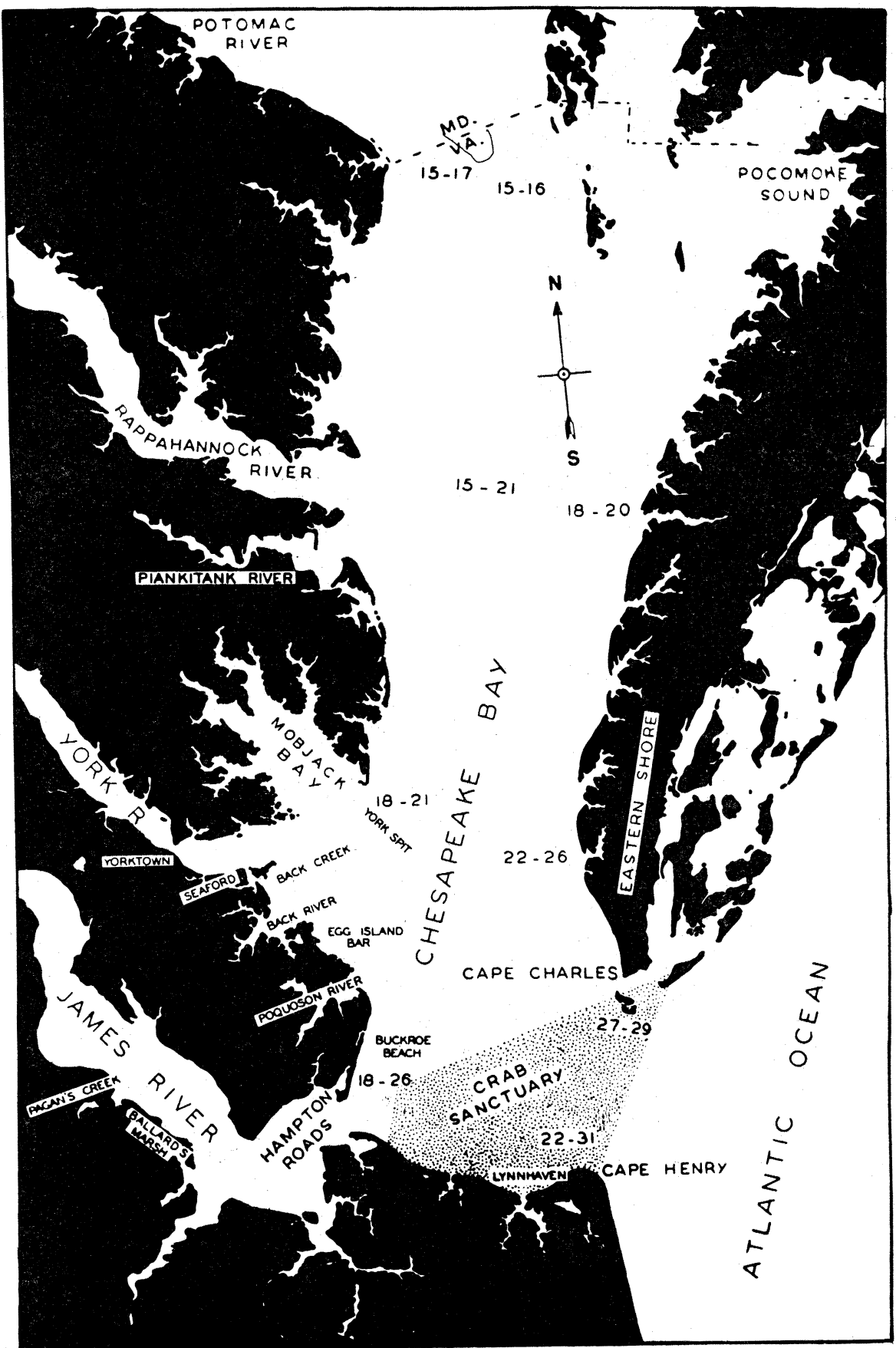

FIgURE 1. Lower Chesapeake Bay, showing the blue crab sanctuary and areas where blue crabs were collected. Average surface-bottom salinity records are given. (After Wells, Bailey, and Henderson, 1929.) Drawn by G. M. Moore. 
females but remain in the rivers and bay waters along the entire length of the bay where they have matured.

The migratory habit of the blue crab endows Maryland seafood dealers with a greater proportion of the soft crab industry because the waters of Maryland and adjoining sections of Virginia are more heavily populated with immature crabs which undergo periodic moltings during their growth. The large population of mature hard crabs in the lower bay is responsible for the crab meat canning industry being located primarily at Hampton, Virginia.

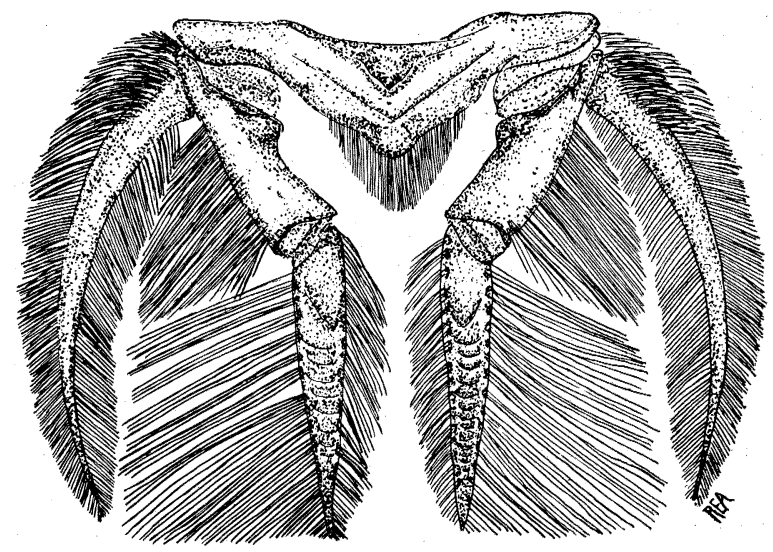

Figure 2. A segment from the abdomen of a female blue crab. Eggs are borne attached to the longer filaments of the endopodite. (Drawn by R. E. Allen.)

To protect the brood stock of blue crabs, the Commission of Fisheries of Virginia maintains a crab sanctuary (Fig. 1) at the mouth of Chesapeake Bay. Optimum conditions exist here for the development of blue crab eggs and crab fishing is prohibited in these waters during the spawning season. Examinations of eggbearing crabs from the sanctuary in 1942 indicated that the fungus parasite, Lagenidium callinectes Couch, occurred there: This discovery aroused a wide interest among fishermen and conservationists and raised a question as to the value of protecting sponge crabs in the area. Furthermore, it pointed to a need for locating the waters where infection exists in order to determine whether the fungus is a general or localized parasite.

\section{Characteristics of the Fungus}

The description of the life history of Lagenidium callinectes Couch (1942) has been a valuable aid in this study. In his observations of the organism Couch found that when germination of the zoospore begins, a delicate germ tube is sent through the egg membranes. This tube grows rapidly into a network of branched mycelium that soon fills the entire egg (Fig. 3). From the mycelium, stumpy, thumb-like projections, or hyphae, pass through the egg membranes to the outside (Fig. 4). These hyphae quickly mature into sporangia which rupture and discharge new spores to continue the cycle of infection. When the nutrient material of the egg has been 
exhausted by the fungus, the mycelium appears to break up into heavy walled, resting cells that seem to be resistant to adverse conditions. However, neither germination of these cells nor a sexual phase of reproduction has yet been observed. Infected eggs soon give definite indication of being abnormal; they are opaque and dwarfed, the diameter becoming reduced from about 290 micra to approximately 231 micra (Fig. 4) (Couch, 1942).

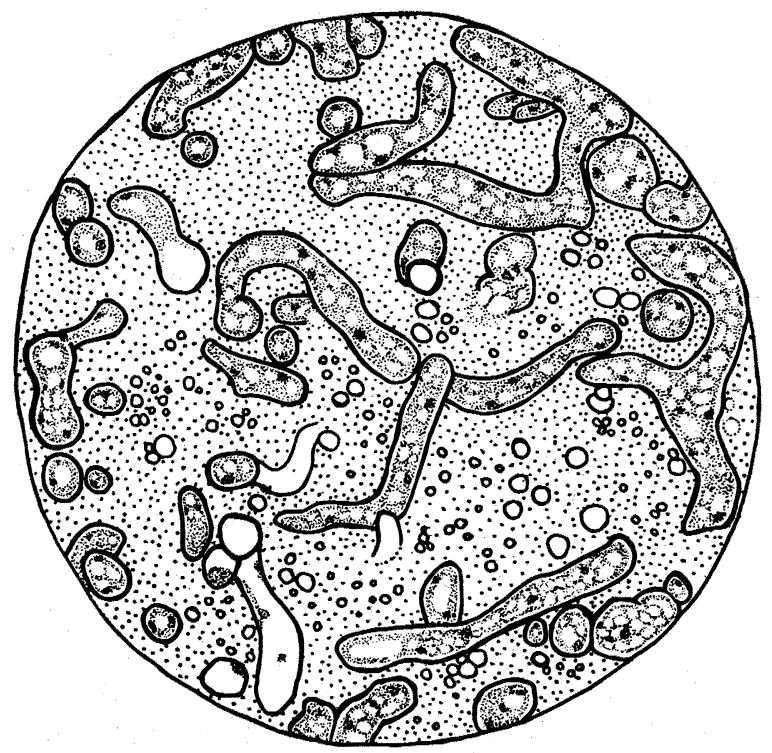

Figure 3. Cross section of a blue crab egg parasitized by Lagenidium callinectes, showing extensive internal mycelium $(400 \dot{X})$.

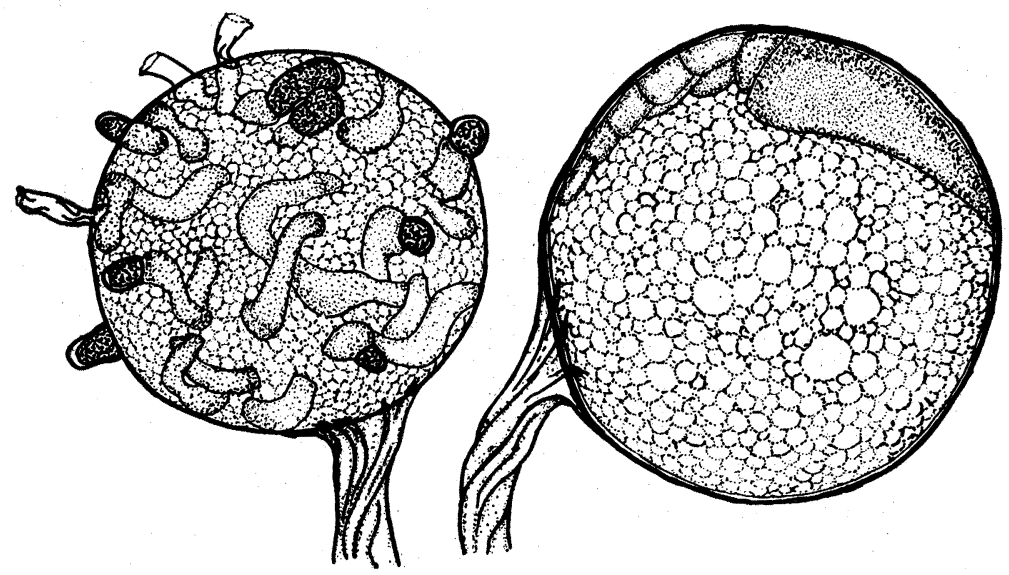

Frgure 4. Two blue crab eggs from a single pleopod filament $(200 \times)$. The parasitized egg (left) demonstrates 8 external hyphae and 3 empty exit tubes. Internal mycelium is seen through the transparent egg membranes. Parasitized egg shows reduction in size. 
The several developmental stages as described by Couch were observed, and it has been possible to maintain the organism under laboratory conditions, thus providing a better understanding of how the parasite destroys the host egg. Among infected eggs collected from Chesapeake Bay and eggs infected under laboratory conditions, the number of external hyphae varies greatly; usually there are one or two on an egg, but frequently nine or more projections are observed at once:

\section{Methods}

Studies of this parasitic fungus were carried out by random sampling of sponge crabs and by microscopic examination of the eggs. Lactophenol was used to clear the eggs and expose the mycelium. In this work the age of the sponge was designated by color: yellow, brown, or black.

Preliminary sampling up to and including 1943 indicated the waters of heaviest infection. Early in 1944 weekly sampling of various crabbing areas was begun. The samples, consisting of 20 to 25 sponges each, were preserved in 10 per cent formalin as soon as the commercial boats docked, which was only a few hours at most after the crabs were removed from the water. Collections were made in the Hampton Roads-Lynnhaven and Egg Island-York Spit areas. Relatively few sponge crabs are found north of York Spit.

To determine the extent of sponge infection, several methods were attempted before a satisfactory one was found. At first, eggs were taken at random from the outside of the mass and examined microscopically. A count totaling 500 eggs was made to estimate the percentage of exterior infection. Then about half the sponge was cut away and the procedure repeated, using eggs from the interior. It was found that infection did not penetrate to the interior, so observations were continued only on the peripheral portion of the sponge. Where infection was observed, several filaments were detached at the base and examined for the progression of fungus along the strand. These methods of computing degrees of infection involved a high probability of error in view of the enormous number of eggs per sponge. It was necessary, therefore, to abandon this plan of estimating the percentage of diseased eggs since it was impossible to count enough in every sponge to determine an accurate percentage.

Satisfactory results were obtained by setting up a standard based on visible areas of infected eggs. When the fungus has spread through many eggs in a given area of a sponge, the diseased portion in contrast to normal eggs assumes a brown color on yellow sponges and a grayish color on brown and black sponges. This is due to opacity of the eggs caused by the parasite. The following classification was adopted for differentiating the infected sponges in routine collections:

Slight-fungus present in microscopic examinations but no areas of infection visible to the naked eye.

Moderate-presence of visible areas of infection (which may be one or more) but less than half the sponge visibly infected.

Heavy-more than half of sponge periphery visibly infected, but with one or two small areas where infection has not become heavy enough to be seen.

Very heavy - a complete peripheral infection with no areas of healthy eggs visible. 
From all the samples collected, four sponges were selected which demonstrated the different degrees of infection. From each pleopod of these sponges, 25 filaments were detached at the base and examined microscopically. Observations were made on the depth of fungus penetration, the general condition of interior eggs, and the posibilities of an appreciable hatch of larvae despite the exterior coat of infection.

Information on transmission of the fungus was obtained using the following procedures :

1. Several infected and uninfected egg-bearing crabs, selected from commercial catches at Seaford and Hampton, were placed together in aquaria.

2. Healthy and infected eggs from two different sponges were placed at opposite ends of porcelain pans and on opposite sides of large finger bowls. Running water from aquaria containing infected crabs was collected in pans into which normal eggs were then introduced. For controls, healthy eggs were placed in pans of water and females with sponges were placed in aquaria.

3. Infected and uninfected sponges in various stages of development were suspended in the York River near shore (Sandoz, Rogers, and Newcombe, 1944). A small cage $(30 \times 13 \times 25 \mathrm{~cm}$. $)$ constructed of window screening on a wooden frame was used to protect the sponges and keep them afloat. Individual pleopods, detached from the sponge, were threaded with string near the base of the protopodite and fastened to hooks inside the cage.

To indicate how the salinity factor affects the fungus, a series of salinities ranging from pond water up to the approximate concentration of sea water was prepared, using pond water and salt extracted from York River water. In filaments selected for these salinity tests, the fungus had attacked all eggs within 2 or $3 \mathrm{~mm}$. of the distal end; below this point eggs were developing normally. One filament was placed in each Petri plate of $50 \mathrm{cc}$. of water.

No other species of crabs has been observed with this infection, so studies were carried out to determine whether or not this parasite has a specific affinity for eggs of Callinectes sapidus. Strands of infected blue crab eggs were placed with the healthy eggs of several other species in Syracuse watch glasses containing York River water. The other forms of crabs included the oyster crab (Pinnotheres ostreum Say, 1817), the wood crab (Sesarma cinereum Bosc, 1801), the mud crab (Neopanope texiana Rathbun, 1900), and the spider crab (Libinia emarginata Leach, 1815), all of which are found in the area where infected blue crabs occur.

\section{Results AND Discussion}

Lagenidium callinectes Couch, a peripheral parasite. Microscopic examinations have shown that infection by $L$. callinectes is restricted principally to the periphery of a sponge (Fig. 5). In fungus infected crabs, all eggs from the distal end of the strand down about $3 \mathrm{~mm}$. may become infected, but below this eggs are found to be normal.

Eggs lying in the interior of a sponge are packed closely together. The filaments, which are found only on the posterior side of the pleopods, vary in length from approximately 3 to $22 \mathrm{~mm}$. (Fig. 2). The longer ones extend from the base of the pleopod while the short ones are at the tip. After eggs have been extruded, this variation permits none of the filaments to be buried within the mass. The volume of eggs is so great that the abdomen is pushed away from the cephalothorax 
and water flows freely around the outside of the sponge. The outer eggs of the mass serve as buffers for those on the interior, since commensals and parasites come in contact with these outer eggs first. Also, interior eggs lie closer together and do not seem to permit a rapid flow of water within the sponge, the interspaces only being large enough for water to seep slowly around the eggs. This movement of water is further aided by activities of the mother crab, such as vigorous jerking of her abdomen and frequent stirring of the eggs with her walking legs. L. callinectes gains a foothold rather quickly, but never seems able to penetrate to great depths
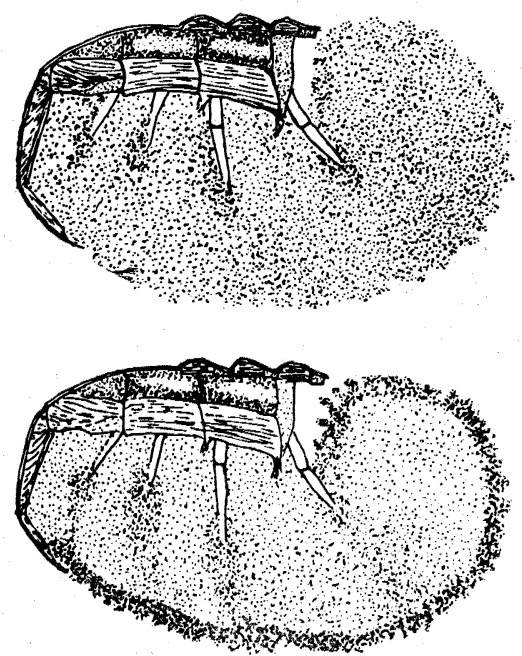

FIgURE 5. Egg masses of Callinectes sapidus Rathbun in longitudinal sections, showing a normal (above) and a diseased (below) condition with peripheral infection.

within the mass. The female's habit of stirring the eggs with her walking legs may provide some opportunity for fungus spores to get into the interior, for in a few cases infection was found at a distance of 5 or $6 \mathrm{~mm}$. down the filament. In only one sponge were infected eggs ever observed at the base of a filament and this filament measured but $13 \mathrm{~mm}$. in length and was located at the outer end of the pleopod. Occurrence of infection inside the sponge, although uncommon, nevertheless provides positive evidence that conditions below the surface of a sponge are suitable for fungus growth. Hence, it seems that the outer eggs must act as a buffer providing a surface for attachment of organisms and a filter for the water that penetrates the sponge.

An infected area of a sponge increases rapidly in diameter while its penetration is much slower. A filament in such an area usually has all the eggs diseased for a length of from one to three millimeters at the distal end. Under the microscope the infection can be seen in various stages. In very heavy infections, the most distal eggs have had their nutrient material exhausted by the mycelium and resting cells have formed while the egg membranes may have started to disintegrate. Adjacent eggs to these have become very opaque and dwarfed and possess external hyphae and sporangia. The diseased eggs which are lowest on the strand are in the earlier 
stages of infection with only one or two empty spore cells on the outside; the internal mycelium is still developing, and very few or no external hyphae are visible.

In this study, examinations were made on disintegrating eggs at the distal ends of the filaments. If the disease destroys eggs rapidly it seems that many of the filaments would lose the cuticular covering which supports the eggs. However, no filaments were found where infection had progressed this far.

$A$ small percentage of eggs destroyed by infection. In laboratory hatching experiments, uninfected egg-bearing filaments yield about a 90 per cent hatch (Sandoz and Rogers, 1944). Numerous empty egg cases observed on sponges removed from spawning grounds also indicate a high hatching percentage of uninfected egg masses in their natural environment. In the case of infected sponges, diseased eggs do not hatch but among the uninfected eggs on the same sponge it was found that the hatching percentage seems to remain high. Several sponges were examined which showed a very heavy peripheral infection beneath which the interior eggs were nearly all hatched out.

On an average-sized sponge of 2,000,000 eggs, about 10 eggs are distributed per millimeter of filament. The average length of all the filaments of a sponge is approximately $12 \mathrm{~mm}$. In very heavy degrees of infection, if the distal $3 \mathrm{~mm}$. of all the filaments were infected, there would be about a 25 per cent infection of the total number of eggs in the sponge. Of the total $2,000,000$ eggs, 75 per cent or $1,500,000$ eggs are in the interior and do not become infected but complete embryonic development and hatch normally. Moreover, a very heavy degree of infection occurs in slightly less than 25 per cent of the sponges; therefore it seems unlikely that $L$. callinectes can be regarded as a factor in the fluctuations of crab populations.

Older sponges more heavily infected. Samples of sponges in any age group show all degrees of infection; in view of which eggs must be susceptible to fungus spores throughout their developmental period. A large number of moderately infected egg masses with diseased patches on opposite sides, or on separate pleopods, indicate that a mass of eggs may be attacked by many spores simultaneously. In most of the sponges where slight infection was present, diseased eggs were found widely distributed over the periphery.

Figure 6 shows the incidence of infection by L. callinectes among sponges of different age groups throughout the summer of 1944 . Less than 50 per cent of the yellow sponges showed infection while both brown and black sponges had a higher percentage of infection. This increase of infection in brown and black sponges is believed to be due to the eggs being older and, hence, exposed to infection for a longer time.

In examining the samples, consideration was given to the amount of infection present on each sponge. The various degrees of infection remained in almost equal proportions throughout the summer, thus indicating a fairly regular cycle for the parasite as regards the continuous infection of sponge crabs during the spawning season.

Zoeal larvae may become infected. In the laboratory, when infected eggs were present in the filaments, zoeae which had hatched normally often showed evidence of the fungus. It is believed that infection could not have occurred before hatching because the mycelium within 48 hours is able to fill an entire egg (Couch, 1942), and in all probability embryonic development would become disturbed within a few 
hours at most after penetration of the spore. The zoeae possess a very thin exoskeleton quite similar in appearance and thickness to the egg membranes which spores penetrate easily. It is more probable that zoeal infection occurs following a normal hatching of the egg. None of the larvae taken from plankton have ever been observed with fungus infection. Infected zoeae have been seen only in laboratory hatching pans, where the larvae must swim about in spore infested water. Under natural conditions larvae hatch from the sponge of the mother crab as she rests on the bottom in warm shallow water. They are positively phototropic and

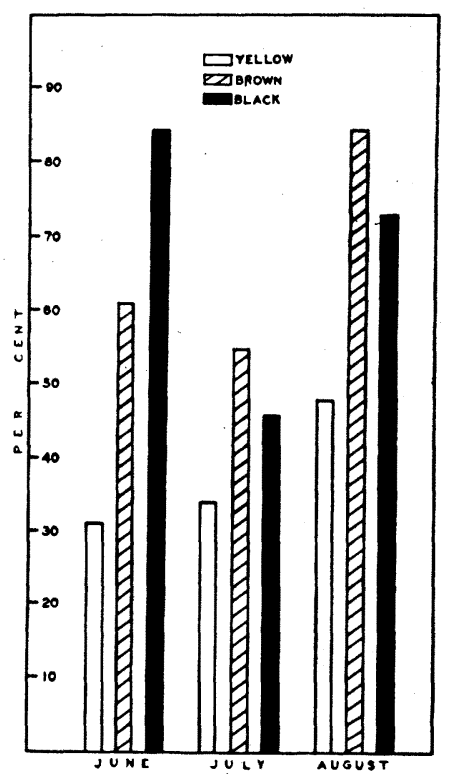

FrguRE 6. Percentage of yellow, brown, and black sponges infected by Lagenidium callinectes. Hampton Roads-Lynnhaven area. 1944.

begin to move toward the surface. In this way the young swim away from the old sponge where infection may have contaminated the surrounding water with many motile spores. When the fungus invades the zoeae, the larvae soon weaken and become unable to swim. If such infection does occur in nature, this would explain the absence of diseased individuals from the plankton samples that we have studied.

Transmission of infection under experimental conditions. Laboratory cultures showed that transmission of infection from one egg to another is extremely rapid. Often an entire pan of eggs was destroyed by disease in three or four days, even when the first day showed very few infected eggs. In aquaria, healthy egg-bearing crabs quickly became infected when diseased crabs were introduced. In one case, water from an aquarium inhabited by a single infected female was used in a hatching pan which contained only normal eggs. Within two or three days $L$. callinectes was seen and a majority of the eggs soon became infected. In other experiments in which diseased and normal eggs were placed at opposite ends of a pan, the fungus was observed to infect the normal eggs after about two days. 
Infected sponges which were suspended in the York River failed to hatch. During the experiment the number of infected eggs increased while the uninfected ones under the same conditions hatched normally, the zoeal larvae escaped and left behind their empty, transparent egg cases.

For experimental purposes normal eggs were usually selected from the Seaford catches where diseased crabs were seldom observed. There is no record of infection in the York River; consequently the chances of fungus having been introduced from the Seaford or York River waters are slight. Examination of controls never showed fungus growth.

Factors affecting the fungus. Laboratory experiments have demonstrated a wide salinity tolerance for this fungus. In all salinities, from 5 to 30 p.p.t., hyphal growth and spore formation proceeded rapidly. In fresh water during a two day period there was some development of external hyphae and a few small abnormal sporangia. During a two day period in salinities of approximately 15, 20, 25, and 30 p.p.t. there was such heavy growth that the eggs appeared to be enveloped in a fine white down. New eggs also became infected. In a salinity of 20 p.p.t. where the parasitic growth was extremely heavy, a typically infected crab egg was observed with seven sporangia, four exit tubes, and four hyphae, all visible from one side.

\section{TABLE I}

Percentage of sponges from Chesapeake Bay infected by Lagenidium callinectes Couch during the period 1942-1944

\begin{tabular}{l|c|c|r|r|r|r}
\hline \hline \multirow{2}{*}{ Location } & Year & $\begin{array}{c}\text { Number of } \\
\text { sponges } \\
\text { examined }\end{array}$ & \multicolumn{2}{|c|}{ Distribution of infection } & $\begin{array}{c}\text { Percentage } \\
\text { of sponge } \\
\text { infection }\end{array}$ \\
\cline { 4 - 6 } & & Yellow & Brown & Black & \\
\hline Lower Bay & 1942 & 82 & 1 & 13 & 19 & 40 \\
Lynnhaven Roads & 1943 & 30 & 3 & 9 & 4 & 53 \\
Lynnhaven Roads & 1944 & 393 & 78 & 104 & 60 & 62 \\
Lynnhaven River & 1943 & 12 & 6 & 1 & 0 & 58 \\
Lynnhaven River & 1944 & 37 & 13 & 8 & 0 & 57 \\
Hampton Roads & 1943 & 15 & 1 & 8 & 4 & 87 \\
Hampton Roads & 1944 & 136 & 20 & 19 & 16 & 40 \\
Ballards Marsh & 1944 & 11 & 0 & 0 & 0 & 0 \\
Seaford & 1943 & 76 & 0 & 0 & 1 & 1 \\
Seaford & 1944 & 254 & 6 & 4 & 4 & 5.5 \\
York River (at York- & 1944 & 63 & 0 & 0 & 0 & 0 \\
$\quad$ town) & & 6 & 0 & 0 & 0 & 0 \\
Rappahannock River & 1943 & 6 & & & & \\
\hline
\end{tabular}

L. callinectes can withstand sudden changes in salinity. The sponge crab used in this experiment was taken from Lynnhaven where the salinity is about 27 p.p.t. She was carried in a moist basket to the laboratory; eggs were cut from the sponge and placed in York River water (salinity 20 p.p.t.) for about an hour. When the salinity series was set up, the sponge filaments were transferred directly to pond water and salinities of $5,10,15,20,25$, and 30 p.p.t. In no case except pond water was there apparent retardation in fungus growth. Development in salinity as low as 5 p.p.t. suggests that it may be possible for L. callinectes to become conditioned to very brackish water. 
Low temperatures were observed to retard fungus development somewhat. This was first noticed in hatching experiments in 1942. When diseased eggs were placed in the refrigerator ( 15 to 16 degrees C.) fungus development and spore formation were delayed. This temperature, however, did not prevent sporulation and the spores continued to swim about, but their movement was sluggish.

Distribution of Lagenidium callinectes in Chesapeake Bay. Extensive samples of sponges collected during 1943-44 have indicated that L. callinectes is quite common in waters extending from Hampton Roads to Cape Henry (Fig. 1). However, the disease is not confined to these open areas. Samples from neighboring places also revealed the existence of fungus in inlets of the region. Samples from several miles up the Lynnhaven River showed a high percentage of fungus occurrence. In August, 1943, a sample from this river showed a 58 per cent infection; in July, 1944, another sample showed a 57 per cent infection (Table 1). In 1942, infected sponges were found in Pagan's Creek, a tributary of the James River. However, in August, 1944, a sample from Ballard's Marsh at the James River Bridge was not infected. In July, 1941, fungus was observed in a sample from Buckroe Beach, which represents the northerly limit of heavily infested waters.

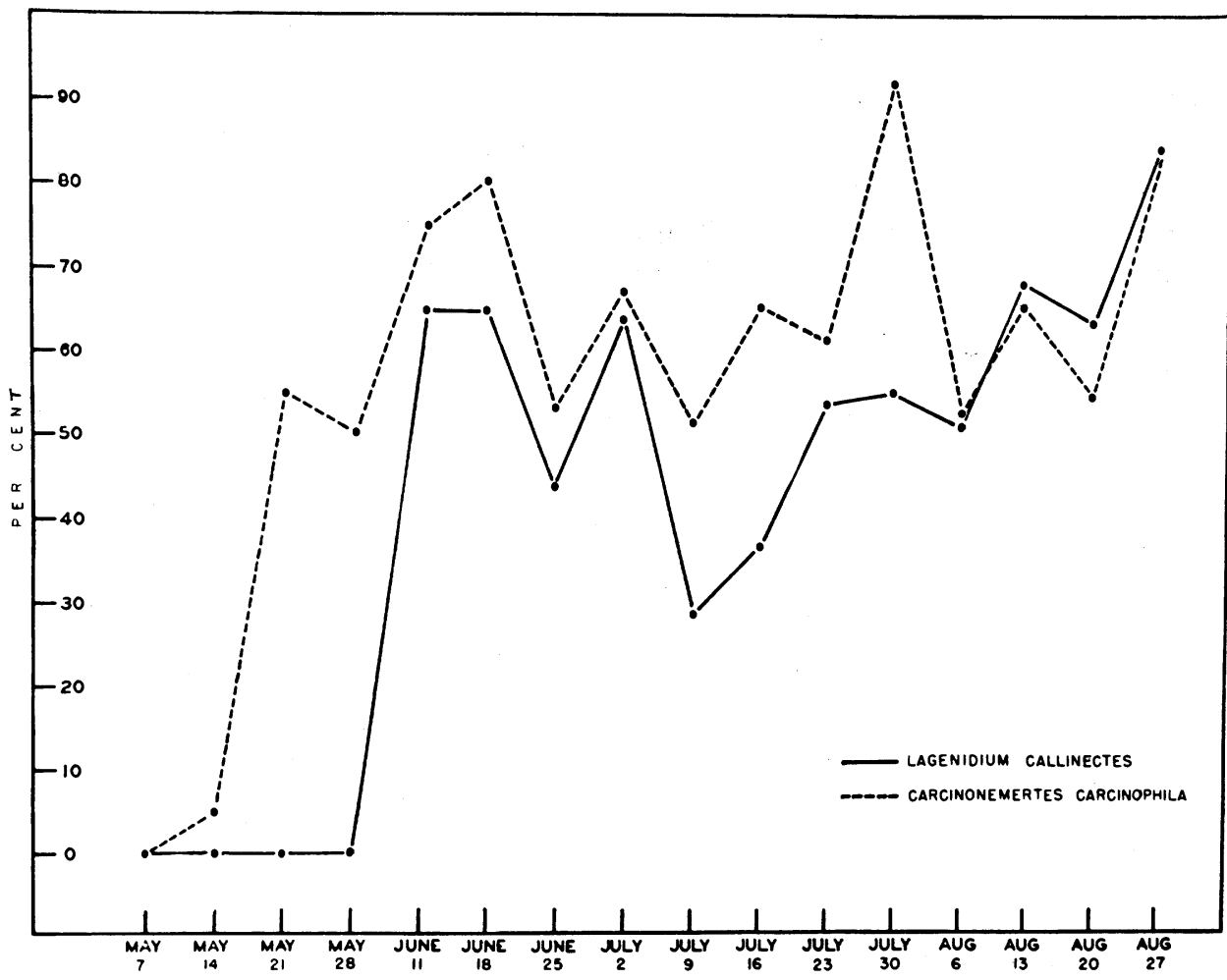

Figure 7. Percentage of blue crab sponges infected by the fungus Lagenidium callinectes Couch and by the nemertine Carcinonemertes carcinophila Kölliker during the summer 1944. Hampton Roads-Lynnhaven area. (Dates indicate first day of the week during which collections were made.) 
In 1944, sponge crabs first appeared in commercial catches during the second week in May. The fungus was not present until a month later, the first record being taken from a sample collected on June 11 in which 13 out of 20 sponges were infected (Fig. 7). There seems to have been a simultaneous appearance of the fungus in both the Hampton Roads and Lynnhaven areas. This would indicate that the organism is well distributed throughout the region, spends a quiescent winter, and becomes active as soon as favorable conditions return. Egg-bearing crabs disappeared soon after August 31, 1944, until which time the fungus was present in more than 50 per cent of the specimens with a small increase during the last of August.

Samples from other regions of Chesapeake Bay have been examined. Throughout the Seaford area infection is uncommon. Several samples taken during June and August showed a 2 to 3 per cent infection. In one sample taken off Egg Island Bar at the mouth of Back River infection occurred in 45 per cent of the sponges. For this region the figure is high; however, Egg Island Bar is located in waters not far distant from Hampton Roads and the sanctuary where there is infection. In the York River at Yorktown, L. callinectes has not been found. One or two infected sponges have been taken from Mobjack Bay, Poquoson River, and the mouths of the York River and Back Creek. The degree of infection in most cases was slight. In these waters however, the majority of spawning crabs are yellow in color and are migrating toward the lower bay where hatching takes place. It is concluded that the general migration to the capes of spawning females is responsible for retaining the infection in this locality. When a female has completed spawning, the fungus probably ceases to live on that individual because hatching has depleted the food supply of the parasite. When the young crabs begin their northward migration, it is believed that the parasite remains behind since there is no evidence of an immature crab harboring the organism. The adult females probably die very soon after the completion of spawning so it is doubtful that spreading up the bay from the Lynnhaven area could occur by migration of infected females. Available information suggests that the fungus is localized in waters where female blue crabs hatch their eggs.

Occurrence of Lagenidium callinectes in other species. Laboratory experiments were carried out in an effort to infect eggs of Pinnotheres ostreum, Neopanope texana, Libinia emarginata, and Sesarma cinereum. The crabs used were all collected in the Seaford-York River region. Within two to five days, fungus was transmitted to eggs of the oyster crab (Pinnotheres ostreum) and the mud crab (Neopanope texiana).

Attempts to transmit fungus to eggs of Libinia emarginata and Sesarmas cinereum were unsuccessful, even though the latter remained alive for more than a week in the laboratory. However, previous hatching experiments with Libinia have never been successful.

Other organisms on the crab sponge. In addition to fungus, other organisms, either parasitic or commensal, are frequently found living on the sponge. These organisms, though quite common, seem to do very little damage to the eggs. Protozoan forms of Carchesium and Ephelota are often attached to the eggs in the peripheral portion of the sponge.

When fungus was first observed on the eggs of Callinectes sapidus, a hair-like growth longer than the diameter of a crab egg was noticed. Some eggs showed a 
profuse development of such filaments which at first were confused with the parasitic fungus. However, the filamentous growth later was recognized to be a Chlamydobacterium (sp.).

In 1944, while conducting crab studies at this laboratory, Dr. Sewell H. Hopkins found the parasitic nemertine Carcinonemertes carcinophila Kölliker (compare Humes, 1942) to be very abundant on the gills of the blue crab. This worm was likewise observed embedded in the sponge where it deposited its own eggs in a case entwined around the filaments. In these observations it was noticed that the nemertine and the fungus frequently occurred together (Fig. 7). The factors governing infection by $L$. callinectes and $C$. carcinophila appear to be quite similar, since the results show a corresponding periodic fluctuation of the two.

Significance of Lagenidium callinectes. From this discussion, Lagenidium callinectes has been found to be a peripheral parasite of the egg mass of the blue crab and the data obtained show that it is present in a large percentage of sponges (Table 1). When present, although it spreads rapidly among the peripheral eggs, penetration into the sponge is slow and rarely deep. Meanwhile, the healthy eggs of the interior, which in all cases represent at least three-fourths of the mass, continue their development and hatch normally.

This parasite, now evidently established within the spawning area, may possess the potential ability to destroy a great number of blue crab eggs. However, in the light of these observations, prevailing natural conditions seem to hold the fungus in check. It is known that the parasite has a fairly wide temperature and salinity tolerance, but the incubation period of the blue crab lasts only about two weeks which appears to be too brief a time for the fungus to work deeply into the center of an egg mass.

\section{SUMMARY}

1. The fungus parasite Lagenidium callinectes Couch has been observed to be a peripheral parasite of egg masses of the blue crabs of Chesapeake Bay.

2. Blue crab eggs are susceptible to infection in all stages of their development. Infected areas of a sponge are brown or gray in appearance, depending on the age of the eggs.

3. While the fungus spreads rapidly over the surface of the sponge, it penetrates the egg mass very slowly. Usually the depth of infection is not over $3 \mathrm{~mm}$.

4. Infection is heavier in older sponges which are brown and black than in younger yellow ones, probably due to the longer exposure of older sponges.

5. Peripheral infection does not seem to retard the development of crab eggs in the interior of the sponge, which far outnumber the peripheral eggs. Not over 25 per cent of the eggs of a heavily diseased sponge are infected and only about 14 per cent of the crabs were found to be heavily infected. However, it was not unusual to find 80 or 90 per cent of the crabs in a sample to have some degree of infection.

6. Under laboratory conditions, transmission of infection from egg to egg of the same and different blue crabs is unexpectedly rapid.

7. Development of the fungus was observed to be abnormal in fresh pond water. In salinities from 5 to 30 p.p.t. development proceeded rapidly and indicated a strong tolerance of changes in salt concentration. 
8. Frequently occurring on the peripheral eggs with Lagenidium callinectes are Carchesium sp., Ephelota sp., and Chlamydobacterium sp. Carcinonemertes carcinophila Kölliker is present and shows periodic fluctuations similar to the fungus.

9. Eggs of the oyster crab and the mud crab became infected with $L$. callinectes under laboratory conditions.

10. The Hampton Roads-Lynnhaven waters is the area in Chesapeake Bay where L. callinectes is most common. Only slight infection was observed north of Buckroe Beach.

\section{LITERATURE CITED}

Churchill, E. P., 1919. Life history of the blue crab. Bull. U. S. Bureau of Fisheries, 36, Document No. 870, 1919, pp. 96-123, Washington, D. C.

Couch, J. N., 1942. A new fungus on crab eggs. J. Elisha Mitchell Scientific Society, 58 (2): $158-162$.

Hopkins, S. H., 1944. The external morphology of the third and fourth zoeal stages of the blue crab, Callinectes sapidus Rathbun. Biological Bull., 87 (2) : 145-152.

Humes, A. G., 1942. Morphology, taxonomy, bionomics of the Nemertine genus Carcinonemertes. Ill. Biol. Monographs, 18, No. 4, 105 pages.

Lochhead, M. S., and C. L. Newcombe, 1942. Methods of hatching eggs of the blue crab. Va. Jour. of Sci., 3: 76-86.

Sandoz, M. D., AND R. Rogers, 1944. The effect of environmental factors on hatching, molting, and survival of zoeal larvae of the blue crab, Callinectes sapidus Rathbun. Ecology, $25: 216-228$.

Sandoz, M. D., R. Rogers, and C. L. Newcombe, 1944. Fungus infection of eggs of the blue crab, Callinectes sapidus Rathbun. Science, 99: 124. 